\title{
Effects of Problem and Project-Based Learning Methods on Students Performance in Building Technology
}

\author{
Yahaya Ibn Salihu, Mohd Safarin Nordin
}

\begin{abstract}
The study was carried out to investigate comparative effects of the problem and project-based learning methods on students' performance in Building Technology. Quasi-experimental study strategy of pre-test, post-test and non-equivalent control group was utilized. The study made use of 148 NCE II students of Building Technology in North-central Nigeria. This comprised 56 students for problem-based learning (PrbL), 47 students for project-based learning (PrjL) and 45 students for control group in the respective intact classes. The task of the teaching methods to classes was completed by simple balloting. Multiple choice test technique was used for data collection. The instrument was content-checked by three specialists while the consistency of the instrument was ascertained through Kuder Richardson 21 (K-R21) that produced 0.83 reliability coefficient. The administration of the pre-test to the three groups took place a week before the commencement of the treatments., The post-test was done to the pupils in the three groups after six weeks. mean and Analysis of Covariance (ANCOVA) at 0.05 level of significance was used to analyze the collected data. The results showed that both PrbL and PrjL methods significantly increased academic performance of students than lecture method. Although the mean performance gains score of the group exposed to PrjL was slightly higher than that of the group exposed to PrbL. There was significant $(p<0.05)$ difference among the mean performances of students in experimental groups and those in control group. Sexual role of the students has no important relationship with their performance in Building Technology Performance Test. The study recommended intensified use of PrbL and PrjL methods for effective instructional delivery in Building Technology.

Index Terms: Problem-based learning, project-based learning, lecture method, academic performance, building technology
\end{abstract}

\section{INTRODUCTION}

Vocational and technical learning is a form of education with the main objective is to prepare the recipients for self or paid employment in any technical and vocational trade on graduation from their training institutions. [1] described it as education designed to impart talents, skills, understanding, attitude, work routines and thankfulness, knowledge and information required by employees to enter and make progress in work on a valuable and creative basis. One of the

Revised Manuscript Received on 14 September, 2019.

Yahaya Ibn Salihu, School of Education, Faculty of Social Science and Humanities,Universiti Teknologi, Malaysia. 81310 Johor Bahru, Johor, Malaysia,yibnsalihu@gmail.com

Mohd Safarin Nordin, School of Education, Faculty of Social Science and Humanities,Universiti Teknologi, Malaysia. 81310 Johor Bahru, Johor, Malaysia,p-safarin@utm.my. areas of specialization in vocational and technical education, as presented in Nigerian tertiary education system, is Building Technology.

Building Technology is designed to be effective and dynamic with several utility purposes which prepare the recipients for active participation in building construction industry in this fast-changing society. Building Technology, according to [2] is a vocational and technical education trade that focuses on the application of engineering principles and technology to design and construct buildings. [3] described Building Technology as a discipline that focuses on the teaching of technical procedures, expertise, procedures, methods, tools and raw materials needed for the construction and maintenance of buildings. [4] submitted that Building Technology education coaches learners within the different building innovation expertise succeed to set up and work small-scale firms such as square industry, generation of pre-cast concrete versatile shafts, concrete rings, course, vases, interlocking tiles, favour squares and bricks among others. [1] affirmed that the aim of Building Technology is to offer technical knowledge and vocational aptitudes essential for industrial development in order to deliver skilled young males and females who will be enterprising in building industry for financial improvement. [5] identified some of the objectives of Building Technology education to include equipping students to realize how to establish a site and be aware with earthwork and formwork in the building sector, be familiar with the techniques involved in solving sub-structural problems and erection of frames, understanding statutory regulation, preliminary works, concrete work, pre-fabrication and plan requirements and understanding the construction of transformation and drainage facilities among others.

In the Nigerian education system, the students of building technology have the choice of being a foreman, craftsmen, and technicians in building sector. The complexities and advancement in present-day building construction and design have necessitated improvement in skills and competencies of building technology graduates. Therefore, greater emphasis must be placed on providing building technology education to students of higher institutions with broad learning and problem-solving skills to prepare them for current technological advancement in building industry. In affirmation, [6] noted that Nigerian employers of labor are looking for workers that

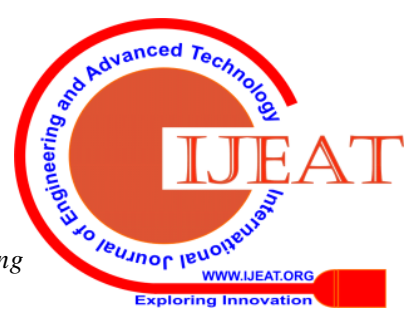


can flexibly attain, adopt, apply and transfer their understanding to diverse situations and under changing technical circumstances and respond autonomously and innovatively in their place of work. Unfortunately, the objective of producing independent and creative technical and vocational education graduates for Nigerian upcoming firms is far from being achieved due to weak quality of graduates as a result of ineffective conventional teaching method mostly use for instructional delivery in our schools.

The conventional method of instruction according to [7] does not substitute critical, creative thinking and collaborative ability to solve problems among students. Similarly, [8] commented that conventional methods of instruction which are mostly used by teachers of technical and vocational education are only content-driven and certainly not learner-centred. [9] also noted that conventional teaching methods are one-way communication methods of instruction that are mainly employed for instructional transfer in Nigerian schools. Therefore, in order to avert the observed poor performance and interest of students in building technology, the use of interactive and learners-centred methods of instruction, for example, problem-based and project-based learning techniques should be more intensified.

Problem-based learning, according to [10] is an approach that is student-oriented through which they study, clarify, and collaborate with the purpose of finding significant way outs to the real-world problems. [11] described problem-based learning as instructional approach that transforms learners into active independent learner instead of passive information receiver. [12] noted that problem-based learning is effective for students to learn, retain, integrate, and apply acquired information. [13] argued that with the use of problem-based learning, students are capable to discover further means of learning to stimulate understanding on how to discover data that are related to the problem and this increases their thinking ability. In affirmation, [14] reported that problem-based learning is made of several steps which include presentation of a real-life problem to students; discussion of the problem and formulation of hypothesis by the students, retrieval of previous understanding and skill relative to the problem, identification of knowledge deficiencies and making research effort to find a solution. Importantly, [15] submitted that problem-based learning authorizes students to conduct research, integrate theory and exercise. Additionally, use understanding and expertise to find a feasible answer to a definite problem and it is an instructional (and curricular) learner-centred approach. Apart from problem-based learning, another notable interactive teaching technique capable of stimulating students' interest and performance as documented in the literature is project-based learning.

Project-based learning has become a preferred teaching technique especially given its attention to real-world scenarios, students' involvement, collaboration and other elements that stimulate active learning. [16] depicted project-based learning as a great strategy for students who don't like just sitting and listening to lectures and it makes strides the basic considering and thought union capacities of the understudies. Project-based learning requires active participation of students and ensures the correlation of the lessons. [17] stated that through project-based learning approach, students find solutions to their problems by asking questions, discussing their opinions, designing experiments, getting and inspecting data, finding results, assigning their opinions and answers to other people and asking new questions. Corroborating its significance in skill acquisition, [18] submitted that project-based learning helps individual learner to improve their group activity expertise, approach, sense of self-concept and studying skills in learning environments based on individual cooperation. Summarily, [19] observed that the key objective of project-based learning is to assist students take responsibility for their own education and boost them to work with others jointly. The projects must be associated with real-life states and students must understand what and why they are learning. In relation to this study, therefore, problem-based learning and project-based learning instructional techniques are highly interactive and learners-centred instructional techniques that can be adopted by building technology lecturers to enhance students' academic performance in Nigerian tertiary institutions.

Academic performance of students, according to [20] is their learning effects which consist of the knowledge, the expertise and involvements learned in lecture hall and laboratory practices. [21] viewed academic performance as a process that involves the students developing on their mental and intellectual capacity. [22] argued that students' achievement is measured by classroom tests or other forms of assessment and is a clear indicator of performances in school subjects. Unfortunately, there seems to be a growing gap between industrial skill needs and the acquired skill performance of most Nigerian graduates of technical and vocational education, building technology inclusive. Interaction by the researchers with both students and graduates of building technology education in north-central Nigeria revealed their obvious deficiency in basic knowledge and skills needed for effective performance in the contemporary building technology industry.

The recent decline in interest and academic performance of students in building technology examinations is worrisome. Often times, poor educational performance of pupils is a product of ineffective instructional delivery methods used by the teachers. For instance, [23] emphasized that learning through conventional methods such as lecture and demonstration methods rather passive but not active. The increasing rates of roads and bridges collapse couple with the current rising trend of building structural defects, failures and collapse that characterized Nigerian building industry has revealed the poor level of competence of most building technicians in the industry. Hence, efforts must be made to strategize building technology education in Nigerian schools through quality and skill-based instructions to produce competent actors in the Nigerian building 
industry. It was based on this yardstick that this study was carried out to investigate effects of problem and project-based learning methods on students' performance in building technology in North-central Nigeria.

\section{METHODS}

\section{A. Design}

This research implemented quasi-experimental research design which is pre-test, post-test, non-equivalent control group design. [24] defined quasi-experimental research design as a design that permits the use of intact classes. [25] stated that quasi-experimental designs recognize a comparison group that is as similar as possible to the treatment group in terms of baseline (pre-intervention) characteristics. The design is illustrated as follows:

$$
\begin{array}{llll}
\mathrm{X}_{1} & \mathrm{O}_{1} & \mathrm{O}_{2} & \text { (Experimental }
\end{array} \text { Group }
$$

Problem-based learning)

$$
\text { - . - . - . - . - . - . . . - }
$$

$\begin{array}{llll}\mathrm{X}_{2} & \mathrm{O}_{1} & \mathrm{O}_{2} & \text { (Experimental }\end{array}$

Project-based learning)

$$
\mathrm{X}_{3} \quad \mathrm{O}_{1} \quad \mathrm{O}_{2} \quad \text { (Control Group) }
$$

Where: $\quad \mathrm{X}_{1}=$ treatment using Problem-based learning $\mathrm{X}_{2}=$ treatment using Project-based learning $\mathrm{X}_{3}=$ Control group (Conventional lecture method)

$$
\begin{aligned}
& \mathrm{O}_{1}=\text { represents test before treatment (pre-test) } \\
& \mathrm{O}_{2}=\text { represents test after treatment (post-test) }
\end{aligned}
$$

The research was completed in the North-central region of Nigeria consist of following six states: Kogi, Niger, Benue, Kwara, Plateau, Nassarawa and the Federal Capital Territory.

\section{B. Population and Sampling Procedures}

Three provinces (Niger, Kogi and Plateau) were arbitrarily chosen out the current six states in North-central Nigeria. From the three nominated provinces, the three colleges which offer Building Technology were examined and one college belonged to each of the three chosen provinces. Therefore, the three selected colleges of education are:

I. Niger State College of Education, Minna with 47 students

II. Federal College of Education, Pankshin, Plateau State with 56 students

III. Kogi State College of Education, Ankpa with 45 students.

Therefore, 148 students were selected as a sample for the study from 2017-2018 session.

The assignment of the classes for teaching methods was prepared through balloting. Hence, Federal College of Education, Pankshin was allocated problem-based learning (PrbL), Niger State College of Education was assigned project-based learning (PrjL) ande Kogi State College of Education was allotted to the conventional lecture method.

\section{Instrument}

Total 50 multiple choice questions were used with the help of Building Technology Performance Test (BTPT) instrument to derive the Data for this research. Every questions were composed of four choices (i), (ii), (iii) and (iv) out of which one choice was the right answer. It was content-validated by three specialists and the reliability was recognized through Kuder Richardson 21 (K-R21) that produced 0.83 reliability coefficient.

\section{EXPERIMENTAL PROCEDURES}

In advance to the beginning of the treatments, all students together in dual experimental sections (PrbL and PrjL) and control group were exposed to pretest to attain the pre-test performance marks. The marks got by students from these three groups denoted their pre-test marks. Afterwards, the real treatment started and continued for six weeks in which students in PrbL groups were educated using Problem-based learning, students in PrjL were trained using Project-based learning whereas students in the control group were educated by conventional lecture method. Everyone has taught Building Technology. After the sixth week of the treatments, the post-test was managed to the students in their particular groups to get the post-test performance marks. The scripts were gathered and marked by the scholar and the students were scored more than 50; because any right solution out of the 50 questions is 1 mark. The data gathered from the three groups in the pre-test and post-test were arranged for analysis.

\section{ANALYTICAL TECHNIQUES}

Data collected were analyzed using mean, standard deviation Analysis of Covariance (ANCOVA) at 0.05 level of significance.

\begin{tabular}{|c|c|c|c|c|c|}
\hline Groups & $\mathbf{N}$ & $\begin{array}{c}\text { Pre- } \\
\mathrm{X}^{-}\end{array}$ & SD & $\begin{array}{r}\mathbf{F} \\
\text { Pre/Po } \\
\text { X }\end{array}$ & $\begin{array}{l}\text { Post-te } \\
\text { st-test } \\
- \\
\text { SD } \\
\text { Gain }\end{array}$ \\
\hline Problem-based & 56 & 23. & 4.4 & 41.18 & 3.48 \\
\hline Learning & & 11 & 5 & & 18.07 \\
\hline Project-based & 47 & 22.8 & 4.3 & 43.04 & 3.2 \\
\hline Learning & & 1 & 1 & & 20.2 \\
\hline Conventional & 45 & 22.9 & 4.2 & 29.24 & 4.2 \\
\hline (Control) & & 3 & 6 & & 6.31 \\
\hline
\end{tabular}

\section{RESULTS AND DISCUSSION}

TAble: Mean Performance SCORES OF BUILding TeChNOLOGY Students taught with Problem and Project-based Learning METHODS AND THOSE TAUGHT WITH CONVENTIONAL METHOD

The result in Table 1 reveals that NCE students taught problem-based learning method had pre-test mean performance score of 23.11, post-test mean score of 41.18 and mean performance gain score of 18.07. [13] affirmed that problem-based learning is an effective method to explain chemistry so as to develop students' critical thinking and problem-solving capabilities. 
The result of [12] revealed that students exposed to problem-based learning method considerably presented high level of accomplishment enthusiasm than the students of control group. A substantial and positive correlation was found between pre and post achievement motivation marks, and substantial change was found in the gain achievement motivation scores of students taught through problem-based learning. [26] confirmed that problem-based learning instruction significantly increases achievement of students in Physics than the use of conventional method. [14] also determined that influence of problem-based learning on performance of students and found that the problem-based learning approach is effective in terms of increased academic achievement of students.

NCE students taught with project-based learning method had pre-test mean performance score of 22.81, post-test mean performance score of 43.04 making their mean performance gain score to be 20.23. In agreement with the findings of this study, [27] established that the project-based learning approach had significantly higher academic achievement effects on students' academic performance than those taught with classical teaching technique. Similarly, [28] observed that students in the project-based learning made superior academic performance than those in control group. This is because students in the treatment group stated typically positive views about the usage of the project-based learning method. [29] found that the use of project-based learning improved students understanding of concepts and helps them to achieve higher behaviour and academic achievement than the use of conventional teaching method.

For the control group that was taught Building Technology with conventional lecture method, their pre-test mean performance score was 22.93 , post-test mean score of 29.24 and mean performance gain score of 6.31. The results noticeably display that the use of problem and project-based learning methods appreciably increased academic performance of NCE students in Building Technology than using classical lecture method for instructional delivery. [30] carried out a study and found that students taught with project-based learning significantly outperformed students taught with discussion, self-regulated learning and the lecture (control) groups. [31] carried out a study by comparing the effects of project-based learning method with lecture method and found that students who were taught with project-based learning method could produce equipment capable of innovative skills needed in meeting global competitiveness.

TABle: Mean Performance SCORES of Male ANd Female Students taught Building Technology With Problem AND ProjeCt-BASED LEARNING MeThODS AND THOSE TAUGHT WITH CONVENTIONAL METHOD

\begin{tabular}{cclcccc}
\hline S & Treatments & Gend & $\mathbf{N}$ & Pre-test & & Gain \\
$\mathbf{N}$ & & er & & Post-tes & Scores \\
& & & $\mathbf{X}$ & t & \\
& & & SD & $-\mathbf{X}$ & \\
& & & & SD & \\
\hline
\end{tabular}

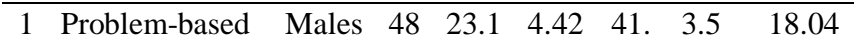
Learning

$3 \quad 17 \quad 2$

\begin{tabular}{|c|c|c|c|c|c|c|c|c|}
\hline \multirow{3}{*}{2} & & les & & 0 & & 25 & 9 & \multirow{3}{*}{20.22} \\
\hline & Project-based & Males & 41 & 22.8 & 4.60 & 43. & 3.2 & \\
\hline & \multirow[t]{3}{*}{ Learning } & & & 2 & & 04 & 6 & \\
\hline & & Fema & 6 & 22.6 & 4.36 & 43. & 3.7 & \multirow[t]{2}{*}{22.33} \\
\hline & & les & & 7 & & 00 & 4 & \\
\hline 3 & \multirow{4}{*}{$\begin{array}{l}\text { Conventional } \\
\text { (Control) }\end{array}$} & Males & 39 & 23.0 & 4.52 & 30. & 4.0 & \multirow[t]{2}{*}{7.11} \\
\hline & & & & 6 & & 17 & 1 & \\
\hline & & Fema & 6 & 22.0 & 3.78 & 29. & 4.5 & \multirow[t]{2}{*}{7.10} \\
\hline & & les & & 1 & & 11 & 3 & \\
\hline
\end{tabular}

The results presented in Table 2 show the effect of gender on the performance scores of NCE students taught Building Technology using problem and project-based learning methods and those taught with conventional lecture method. The results show that male students taught Building Technology with problem-based learning method had pre-test mean performance score of 23.13 , post-test mean performance score of 41.17 and mean performance gain of 18.04. Female students taught with problem-based learning method had pre-test mean performance score of 23.00, post-test mean performance score of 41.25 and mean performance gain of 18.25 in Building Technology performance test. [32] studied gender differences in electricity interest and achievement scores using problem-based learning. The results showed that there was no significant difference between the mean achievement scores of gender-based students when taught electricity using problem-based learning approach. [33] investigated problem-based learning and students' academic achievement on thermodynamics and found that gender had no significant effect on the students' mean achievement scores when taught with problem-based learning approach.

On the other hand, male students taught Building Technology with project-based learning method had a mean performance score of 22.82 in the pre-test, 43.04 in the post-test making their mean performance gain to be 20.22. The female students taught with project-based learning had pre-test mean performance score of 22.67, post-test score of 43.00 and performance gain score of 22.33 in Building Technology test. The result of [34] showed no significant gender difference as project-based learning had a positive effect on both male and female students. [35] investigated inquiry project-based learning and found that gender (male and female) differences and academic abilities had no significant moderating effects on the learning dimensions.

For the control group, male students taught Building Technology with conventional lecture method had a mean performance score of 23.06 in pre-test, 30.17 in post-test, therefore making their mean performance gain to be 7.11. The female students in control group had mean performance score of 22.01 in pre-test, 29.11 in post-test and mean performance gain of 7.10 . This outcome specifies that both problem and 
project-based learning methods considerably increased academic performance of male and female students in Building Technology than conventional lecture method. Although, students taught with project-based learning had relatively higher performance gain score than those taught with problem-based learning.

TABLE 3: ANALYSIS OF COVARIANCE (ANCOVA) OF NO SIGNIFICANT EFFECTS OF Treatments (Problem and ProjeCt-Based Learning Methods) ANd Gender on ACAdemic Performance of Students in BUILDING TECHNOLOGY TEST.

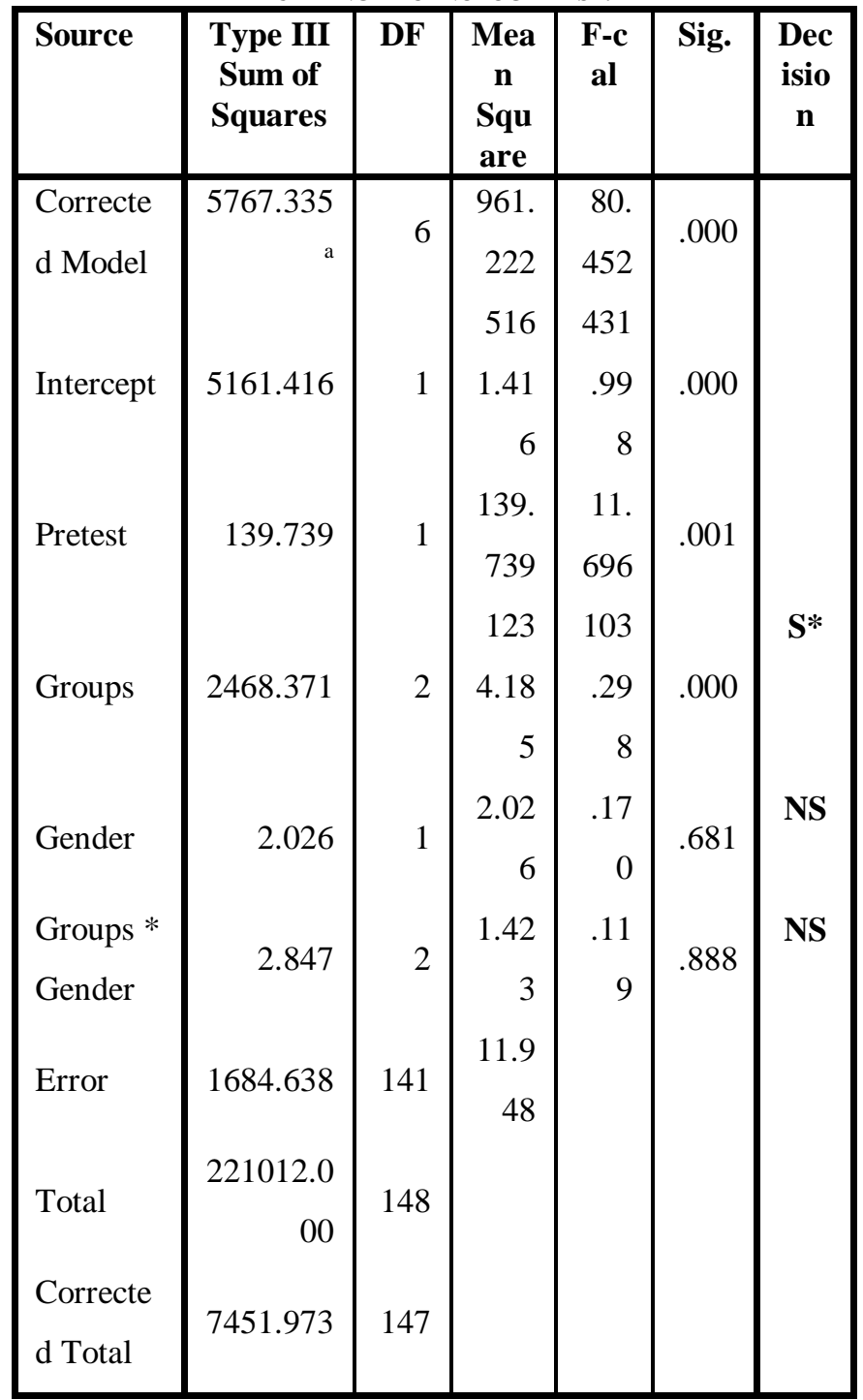

Note: $\mathbf{R}^{2}=0.774 ;$ Adjusted $\mathbf{R}^{2}=0.764 ; \mathbf{S}^{*}=$

Significant, NS $=$ Not Significant at 0.05 .

The result presented in Table 3 shows that treatment (Groups) as the main factor had an important effect on students' performance. The F-calculated (F-cal) value of 103.298 and the $\mathrm{p}$-value of 0.000 that is less than 0.05 level of significance specify important modification in the mean performance scores of students taught with problem and project-based learning methods and conventional lecture method based on the treatments given. For the effect of gender on academic performance in Building Technology, the result shows that the F-calculated value of 0.170 and p-value of 0.681 which was greater than 0.05 level of significance indicate that there was no significant difference in the mean achievement scores of male and female students in the Building Technology performance test. [32] reported that gender is not a significant factor in respect to effects of problem-based learning on students' academic performance. [36] found that there is no important difference among the mean achievement scores of male and female students taught algebra using problem-based learning approach. [34] found that project-based learning had a positive effect on both male and female students, hence, suggesting that project-based learning is not gender-sensitive.

The result of interaction effects of gender and teaching methods (Group*Gender) shows F-calculated (F-cal) value of 0.119 with a p-value of 0.888 which is greater than 0.05 level of significance. This indicates that there was no significant interaction effect between the treatments (Groups) and gender of the students with respect to Building Technology performance test.

\section{CONCLUSION}

The current unemployability status of most graduates of Building Technology and incessant cases of building failure and collapse in Nigeria had revealed beyond doubt that the competence of most of the technicians in Nigerian Building industry is questionable. Hence, the objective of producing competent Building Technology graduates as quality manpower in the Nigerian building industry has not been achieved. Therefore, greater emphasis must be placed on providing quality Building Technology education to students through interactive, broad learning and skill-based methods of instruction. Therefore, this study was carried out to comparatively investigate effects of problem-based learning and project-based learning methods on students' performance in Building Technology using North-central Nigeria as case study. The results showed that both problem-based learning and project-based learning methods significantly increased academic performance of students than lecture method. Although, the mean performance gains score of the group exposed to project-based learning was slightly higher than that of the group exposed to project-based learning. The result of the study further shows that problem and project-based learning are not gender-sensitive as the two learning methods showed no significant interaction with gender of students. There was significant difference between the mean performances of students in experimental groups (problem and project-based learning methods) and those in control group. The study recommended:

1. Increased use of problem-based and project-based learning methods by technical and vocational education teachers for effective instructional delivery in Building Technology.

2. Government at all levels should formulate applicable strategies to reinforce problem-based and project-based learning methods in Nigerian technical and vocational.

3. Efforts should be made by government and school administrators for the acceptable facility of relevant instructional materials to help quality teaching and learning with project-based

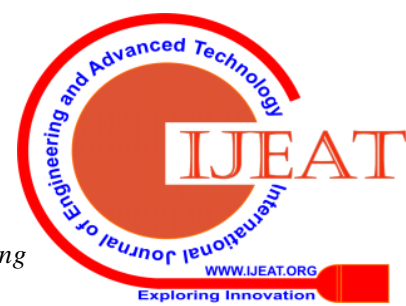


project-based learning techniques.

4. There should be skill update and timely in-service training to teachers and lecturers of technical and vocational education for effective application of problem-based and project-based learning methods that are interactive and student-centred.

\section{REFERENCES}

[1] M. J, Effieyen., P. B, Asu-nandl., and N. E, Achima. "Entrepreneurial Skills Development and the Building Technology Curriculum". Niger Delta Journal of Education, 3 (1): 600 - 607, 2017.

[2] J. E, Maurice., P. B, Asu-nandi and E. A. Ntui, "Skills development in Building Technology". Niger Delta Journal of Education (NDJOE), 3 (1): $306-317$.

[3] C. E, Okoro, "Innovations in Building Technology and Curriculum Revision Needs for Building Construction Programmes of Colleges of Education (Technical)". An Unpublished Masters Project, Department of Vocational Teacher Education (Industrial Technical Education) University of Nigeria, Nsukka, 2010.

[4] C. O, Igwe., S. T, Puyate., C. E. C, Onoh and C. J Eze, "Entrepreneurial and Functional Building Technology Education as a Means of Achieving Vision 2020 in Nigeria". Journal of Education and Vocational Research, 3 (9): $291-296,2012$.

[5] D, Gimba, "Employability Skills Required by Polytechnic Graduates Building Technology in Nigeria". An Unpublished Masters Project, Department of Vocational Teacher Education, University of Nigeria, Nsukka, 2011.

[6] B. A, Ogwo, "Modern Institutional Techniques and their Application in TVE Programmes of Polytechnic". A Commissioned Paper Presented at Capacity Building Workshop for Lecturers of Polytechnic and Monotechnics in Nigeria Organized by the Education Trust Fund (ETF) Held at Auchi Polytechnics on 2nd November, 2005.

[7] T. V, Akpoghol., F. O., Ezeudu., J. N Adzape and E. E, Otor, "Effects of Lecture Method Supplemented with Music and Computer Animation on Senior Secondary School Students' Academic Achievement in Electrochemistry". Journal of Education and Practice, 7 (4): 75 - 86, 2016.

[8] R. N, Oranu, "Vocational and Technical Education in Nigeria". Available on line through http://www.ibe.co.org/curriculum/, 2003.

[9] J, Unongo, "Comparative Effects of Dialogic Teaching and Coaching Instructional Strategies on Students' Performance, Interest and Retention in Motor Vehicle Mechanic Works in Technical Colleges in Benue State". Unpublished Ph.D Thesis, Submitted to the Department of Vocational Teacher Education, University of Nigeria, Nsukka, 2015.

[10] L, Torp and S, Sage, "Problems as possibilities: Problem-based learning for K-12 education". ASCD, 2002.

[11] O, Akinoglu and R, Tandogan, "The effects of problem-based active learning in science Education on students' academic achievement, attitude and concept Learning”. Eurasia J. Math. Sci. Technol. Edu. 3(1): $71-81,2007$.

[12] P, Thakur and S, Dutt, "Problem-based learning in biology: Its effect on achievement motivation of students of 9th standard". International Journal of Multidisciplinary Education and Research, 2 (2): 99 - 104, 2017.

[13] B, Aidoo., S. K, Boateng., P. S, Kissi and I. Ofori, "Effect of Problem-Based Learning on Students' Achievement in Chemistry". Journal of Education and Practice, 7 (33): 103 - 108, 2016.

[14] M. O, Abanikannda, "Influence of Problem-Based Learning in Chemistry on Academic Achievement of High School Students in Osun State, Nigeria". International Journal of Education, Learning and Development, 4 (3): $55-63,2016$.

[15] J. R, Savery, "Overview of Problem-based Learning: Definitions and Distinctions. Interdisciplinary Journal of Problem-Based Learning", (1): Retrieved from https://dx.doi.org/10.7771/1541-5015.1002, 2006

[16] B, Ibrahim., K, Yunus and A, Yusuf, "The Effects of Project Based Learning on Undergraduate Students' Achievement and Self-Efficacy Beliefs towards Science Teaching", Eurasia Journal of Mathematics, Science and Technology Education, 11 (3): 469 - 477, 2015

[17] E, Erdem, "Examination of the Effects of Project Based Learning Approach on Students' Attitudes towards Chemistry and Test Anxiety". World Applied Sciences Journal, 17 (6): 764 - 769, 2012.

[18] N, Kalayci, "An Application Related to Project Based Learning in Higher Education Analysis in Terms of Students Directing the Project". Education and Sci., 147 (33): 85 - 105, 2008.

[19] K, Cole., B, Means., M, Simkins and F, Tavali, "Increasing student learning through multimedia projects". Virginia, Alexandria (USA) Association for Supervision and Curriculum Development, 2002.
[20] A. O, Akinbobola, "Effects of Cooperative and Competitive Learning Strategies on Academic Performance of Students in Physics". Journal of Research in Education, 3: 1-5, 2016.

[21] S. A, Akinade, "A Structural Model for Predicting Mathematics Achievement: it's Relation with Anxiety and self concept in mathematics." Psychological reports, 86: $835-847,2001$

[22] E. E. U, Fstan, "Effect of Peer Tutoring On Students' Academic Performance and Retention in Junior Secondary School Basic Science". International Journal of Educational Benchmark (IJEB), 3 (1): 91 - 100, 2016.

[23] A. C, Ifeakor., C. B, Njelita and M. E, Udogu, "An appraisal of senior secondary school teachers' awareness and usage of innovative instructional strategies and evaluation techniques in teaching chemistry". Proceedings of the 49th Annual Conference of STAN, 116 - 121, 2008.

[24] M. D., Gall, J. P, Gall and and W. R, Borg, "Educational Research: An Introduction. (Eight Edition)". Boston,New York: Pearson Education Inc, 2007.

[25] [25] W, Howard and S, Shagun, "Quasi-Experimental Design and Methods. Methodological Briefs, Impact Evaluation No. 8". New York: United Nations International Children's Emergency Fund (UNICEF), 2014.

[26] A. S, Argaw., B. B, Haile., B. T., Ayalew and S. G, Kuma, "The Effect of Problem Based Learning (PBL) Instruction on Students' Motivation and Problem Solving Skills of Physics". EURASIA Journal of Mathematics Science and Technology Education. 13 (3): 857 - 871, 2016.

[27] K, Redmond, The Effects of Project-Based Learning on Student Achievement in a Fourth Grade Classroom". An Unpublished Masters Project sbmitted to Department of Science Education, Montana State University Bozeman, Montana, 2014.

[28] I, Bilgin., Y, Karakuyu and Y, Ay, "The Effects of Project Based Learning on Undergraduate Students' Achievement and Self Efficacy Beliefs towards Science Teaching". Eurasia Journal of Mathematics, Science \& Technology Education, 11 (3): 469 - 477, 2015.

[29] I, Ilter, "A study on the Efficacy of Project Based Learning Approaches on Social Studies Education: Conceptual Achievement and Academic Motivation”. Education Research and Review. 9 (15): 487 - 497, 2014.

[30] O. D, Uzoma and G. N, Amadi, "Differential effects of project based, group discussion and self-regulated learning techniques on students' achievement in Biology". International Journal of Education, Learning and Development, 5 (4): 96 - 108, 2017.

[31] S, Alachi., A. B, Owadara and A. O, Iwu, "Effect of project-based method on students' achievement in physics- implication for global competitiveness". JORIND 14 (1): 1 - 11, 2016

[32] J. O, Omaga, "Gender Differences in Electricity Interest and Achievement Scores: A case of Problem Based Learning (PBL) Approach". International Journal of Innovative Social \& Science Education Research, 5(2): $9-15,2017$.

[33] R. U, Etiubon and A. U, Ugwu, "Problem-Based Learning and Students' Academic Achievement on Thermodynamics (A case study of University of Uyo, Akwa - Ibom state, Nigeria)". IOSR Journal of Research and Method in Education, 6 (5): 36 - 41, 2016.

[34] [34] G, Murat, "The project-based learning approach in environmental education". International Research in Geographical and Environmental Education, 24 (2): 105 - 117, 2015.

[35] [35] S, Chu, "Inquiry project-based learning with a partnership of three types of teachers and the school librarian". Journal of the American Society for Information Science and Technology, 60(8): 1671 - 1686, 2009.

[36] O, Emmanuel., C. S, Abonyi., G, Okafor and C, Omebe, "Effects of Problem-Based Learning Approach on Junior Secondary School Students' Achievement in Algebra”. Journal of the Science Teachers Association of Nigeria, 50 (1): $57-68,2015$

\section{Author Profile}

Yahaya Ibn Salihu

I am Yahaya Ibn Salihu and I am affiliated with School of Education, Faculty of Social Science and Humanities,Universiti Teknologi, Malaysia. 81310 Johor Bahru, Johor, Malaysia,yibnsalihu@gmail.com

Mohd Safarin Nordin

I am Mohd Safarin Nordin and I ma affiliated with School of Education, Faculty of Social Science and Humanities,Universiti Teknologi, Malaysia. 81310 Johor Bahru, Johor, Malaysia,p-safarin@utm.my. 